\title{
Comparison Between Problem-Based Learning and Lecture-Based Learning: Effect on Nursing Students' Immediate Knowledge Retention [Response To Letter]
}

This article was published in the following Dove Press journal:

Advances in Medical Education and Practice

\section{Yonatan Solomon (ID}

Department of Nursing, College of Medicine and Health Sciences, Dire Dawa University, Dire Dawa, Ethiopia
Correspondence: Yonatan Solomon Tel +25l 913820259

Email yonatnsolomon@gmail.com

\section{Dear editor}

I am very glad to hear from you and happy to see the letter of response from the author Rahul Penumaka showing interest in the publication "Comparison Between Problem-Based Learning and Lecture-Based Learning: Effect on Nursing Students' Immediate Knowledge Retention"

Saying this I think I need to respond to some of the points raised:

1. "Notably, each group was exposed to only one teaching intervention which makes it difficult to compare student preferences. Preference may have been influenced by previous teaching experiences or a lack of familiarity with problem-based learning."

Response: Though grouping was done for just the purpose of comparing their effect for the study objective; students have been exposed to both teaching methods starting from their 1st year, 1st semester class, so neither of the methods are new for the students.

2. "Different teachers were employed for each teaching session and thus, individual teaching style and ability could have influenced student's perceptions of each method."

Response: Even though I share and appreciate your concern, individual teaching ability cannot be at a similar stage or cannot perform in a similarly equal manner. But, to minimize this, the author assigned instructors who are MSc holders and have a trainer of trainee (ToT) in PBL development, administration, facilitation and assessments of the method. So, the author believes this will minimize the problem.

3. "The outcome measures of this study were immediate knowledge retention and student preference. While immediate retention is important, it is perhaps not the most relevant measure for nursing students. Instead, long-term knowledge retention and the ability to apply information may be more pertinent." 
Response: As you have already said, immediate knowledge retention is important; we cannot talk about long term knowledge retention without improving the immediate knowledge retention of our students. Though there is no denial on the very importance of long-term retention the author believes that we need to give attention to the student's immediate knowledge retention, which is the ground and stepping-stone for long term knowledge retention.

4. "This may not have been evident to first-year students unfamiliar with clinical practice. Students may have rated problem-based learning lower because they did not see the relevance of learning application and decision-making skills. Instead preferring a didactic teaching style which they are familiar with.”

Response: According to the Ethiopian nursing education curriculum, students will be exposed to clinical practice starting from the 1st year, 1st semester which means the result has not come from lack of exposure to clinical experience.

Again, I am really happy for your interest in my published work.

\section{Disclosure}

The author reports no conflicts of interest in this communication.

Dove Medical Press encourages responsible, free and frank academic debate. The content of the Advances in Medical Education and Practice 'letters to the editor' section does not necessarily represent the views of Dove Medical Press, its officers, agents, employees, related entities or the Advances in Medical Education and Practice editors. While all reasonable steps have been taken to confirm the content of each letter, Dove Medical Press accepts no liability in respect of the content of any letter, nor is it responsible for the content and accuracy of any letter to the editor.

\section{Publish your work in this journal}

Advances in Medical Education and Practice is an international, peerreviewed, open access journal that aims to present and publish research on Medical Education covering medical, dental, nursing and allied health care professional education. The journal covers undergraduate education, postgraduate training and continuing medical education including emerging trends and innovative models linking education, research, and health care services. The manuscript management system is completely online and includes a very quick and fair peer-review system. Visit http://www.dovepress.com/testimonials.php to read real quotes from published authors. 